\title{
Decision to Emigrate Amongst the Youth in Lebanon
}

GHASSAN DIBEH

ALI FAKIH

WALID MARROUCH 


\title{
2017s-04
}

\section{Decision to Emigrate Amongst the Youth in Lebanon}

\author{
Ghassan Dibeh, Ali Fakih, Walid Marrouch
}

Série Scientifique
Scientific Series

\section{Montréal \\ Janvier/January 2017}

(C) 2017 Ghassan Dibeh, Ali Fakih, Walid Marrouch. Tous droits réservés. All rights reserved. Reproduction partielle permise avec citation du document source, incluant la notice $\odot$.

Short sections may be quoted without explicit permission, if full credit, including $@$ notice, is given to the source.
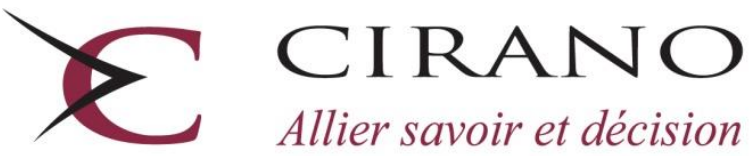

Allier savoir et décision

Centre interuniversitaire de recherche en analyse des organisations 


\section{CIRANO}

Le CIRANO est un organisme sans but lucratif constitué en vertu de la Loi des compagnies du Québec. Le financement de son infrastructure et de ses activités de recherche provient des cotisations de ses organisations-membres, d'une subvention d'infrastructure du gouvernement du Québec, de même que des subventions et mandats obtenus par ses équipes de recherche.

CIRANO is a private non-profit organization incorporated under the Quebec Companies Act. Its infrastructure and research activities are funded through fees paid by member organizations, an infrastructure grant from the government of Quebec, and grants and research mandates obtained by its research teams.

\section{Les partenaires du CIRANO}

\section{Partenaires corporatifs}

Autorité des marchés financiers

Banque de développement du Canada

Banque du Canada

Banque Laurentienne du Canada

Banque Nationale du Canada

Bell Canada

BMO Groupe financier

Caisse de dépôt et placement du Québec

Fédération des caisses Desjardins du Québec

Gaz Métro

Hydro-Québec

Innovation, Sciences et Développement économique

Intact

Investissements PSP

Ministère de l'Économie, de la Science et de l'Innovation

Ministère des Finances du Québec

Power Corporation du Canada

Rio Tinto

Ville de Montréal

Partenaires universitaires

École Polytechnique de Montréal

École de technologie supérieure (ÉTS)

HEC Montréal

Institut national de la recherche scientifique (INRS)

McGill University

Université Concordia

Université de Montréal

Université de Sherbrooke

Université du Québec

Université du Québec à Montréal

Université Laval

Le CIRANO collabore avec de nombreux centres et chaires de recherche universitaires dont on peut consulter la liste sur son site web.

Les cahiers de la série scientifique (CS) visent à rendre accessibles des résultats de recherche effectuée au CIRANO afin de susciter échanges et commentaires. Ces cahiers sont écrits dans le style des publications scientifiques. Les idées et les opinions émises sont sous l'unique responsabilité des auteurs et ne représentent pas nécessairement les positions du CIRANO ou de ses partenaires.

This paper presents research carried out at CIRANO and aims at encouraging discussion and comment. The observations and viewpoints expressed are the sole responsibility of the authors. They do not necessarily represent positions of CIRANO or its partners.

ISSN 2292-0838 (en ligne) 


\title{
Decision to Emigrate Amongst the Youth in Lebanon*
}

\author{
Ghassan Dibeh ${ }^{\dagger}$, Ali Fakih ,Walid Marrouch $^{\S}$
}

\section{Résumé/abstract}

This paper studies the determinants of youth emigration decisions, which is considered to be one of the main causes of 'Brain Drain' in Arab Mediterranean Countries (AMCs). We focus on the case of Lebanon using a unique dataset covering young people aged 15 to 29 from the year 2016. The aim of the paper is to identify the profile of youth's propensity to emigrate from Lebanon. The empirical results indicate that youth from non-wealthy backgrounds living in smaller dwellings have a higher propensity to emigrate. It is also found that being male and unemployed has a positive incidence on migration. Moreover, university education promotes the willingness to emigrate; while residents of poor regions are more likely to express such willingness. Finally, the paper provides some insights for policymakers.

Mots clés/keywords: Emigration; youth; Lebanon; probit model.

Codes JEL/JEL codes: C25; J60; O15

\footnotetext{
* The research leading to these results has received funding from the European Community's Seventh Framework Programme FP7/2007-2013 under grant agreement $n^{\circ} 613174$ for the SAHWA Project (www.sahwa.eu). The SAHWA Project ("Researching Arab Mediterranean Youth: Towards a New Social Contract") is a FP-7 interdisciplinary cooperative research project led by the Barcelona Centre for International Affairs (CIDOB) and funded by the European Commission. It brings together fifteen partners from Europe and Southern and Eastern Mediterranean countries to research youth prospects and perspectives in a context of multiple social, economic and political transitions in five Arab countries (Morocco, Algeria, Tunisia, Egypt and Lebanon). The project expands over 2014-2016 and has a total budget of $€ 3.1$ million. The thematic axes around which the project will revolve are education, employment and social inclusion, political mobilisation and participation, culture and values, international migration and mobility, gender, comparative experiences in other transition contexts and public policies and international cooperation.

† Lebanese American University. Email: gdibeh@lau.edu.lb.

* Lebanese American University, CIRANO, and IZA. Email: afakih@lau.edu.lb.

${ }^{\S}$ Lebanese American University and CIRANO. Email: walid.marrouch@lau.edu.lb.
} 


\title{
Decision to Emigrate Amongst the Youth in Lebanon
}

\author{
Ghassan Dibeh \\ Lebanese American University \\ gdibeh@lau.edu.lb
}

Ali Fakih

Lebanese American University, CIRANO, and IZA

afakih@lau.edu.lb

Walid Marrouch

Lebanese American University and CIRANO

walid.marrouch@lau.edu.lb

\begin{abstract}
This paper studies the determinants of youth emigration decisions, which is considered to be one of the main causes of 'Brain Drain' in Arab Mediterranean Countries (AMCs). We focus on the case of Lebanon using a unique dataset covering young people aged 15 to 29 from the year 2016. The aim of the paper is to identify the profile of youth's propensity to emigrate from Lebanon. The empirical results indicate that youth from non-wealthy backgrounds living in smaller dwellings have a higher propensity to emigrate. It is also found that being male and unemployed has a positive incidence on migration. Moreover, university education promotes the willingness to emigrate; while residents of poor regions are more likely to express such willingness. Finally, the paper provides some insights for policymakers.
\end{abstract}

Keywords: Emigration; youth; Lebanon; probit model

JEL Classification: C25; J60; O15

\section{Acknowledgements}

The research leading to these results has received funding from the European Community's Seventh Framework Programme FP7/2007-2013 under grant agreement $\mathrm{n}^{\circ} 613174$ for the SAHWA Project (www.sahwa.eu). The SAHWA Project ("Researching Arab Mediterranean Youth: Towards a New Social Contract") is a FP-7 interdisciplinary cooperative research project led by the Barcelona Centre for International Affairs (CIDOB) and funded by the European Commission. It brings together fifteen partners from Europe and Southern and Eastern Mediterranean countries to research youth prospects and perspectives in a context of multiple social, economic and political transitions in five Arab countries (Morocco, Algeria, Tunisia, Egypt and Lebanon). The project expands over 2014-2016 and has a total budget of $€ 3.1$ million. The thematic axes around which the project will revolve are education, employment and social inclusion, political mobilisation and participation, culture and values, international migration and mobility, gender, comparative experiences in other transition contexts and public policies and international cooperation. 


\section{Introduction}

Youth emigration, encouraged by political instability and social fractionalization, is considered to be one of the main causes of 'Brain Drain' in Arab Mediterranean Countries (AMCs) (Docquier et al., 2007). In Lebanon, youth emigration has affected negatively economic growth and the accumulation of human capital. It also acted as a channel for the youth to cope with unemployment, lack of long term career prospects, and rigid social mobility. The objective of this paper is to explore empirically a number of socio-economic drivers behind the decision of youth to emigrate from Lebanon.

The economics literature on international migration is classified into three lines of research (Borjas, 1989; Borjas and Bratsberg, 1996): the determinants of migration flows, the integration of migrants in host countries, and the economic impact of migration in origin and host country. This study falls within the first line of research that investigates the determinants of migration flows. The study of these determinants allows policymakers to identify areas for policy intervention to mitigate the negative implications of this phenomenon. This is especially important for Lebanon, where emigration is negatively affecting the economic system and demographic structure. Specifically, we explore the role of microeconomic factors using a unique dataset from Lebanon covering young people aged 15 to 29 . This empirical investigation using microdata enhances our understanding of the decision of youth to emigrate from Lebanon. To the best of our knowledge, this is the first study that aims to quantify these effects using a comprehensive and representative dataset on the youth population in the country.

According to the World Bank, it is estimated that the average net migration rate in Lebanon is 21.29 per 1000 inhabitants over the period 2010-2015 (World Development Indicators, 2015). ${ }^{1}$ Over that period, the migration rate in Lebanon is positive because of the Syrian refugees' influx into Lebanon in the aftermath of the Syrian crisis that has been ongoing since 2011. To put that number in perspective, it is important to know that the current stock of Syrian refugees in Lebanon is around one million refugees which is around one fourth of the Lebanese population. However, between the end of the civil war in 1990 and 2010, the rate has been either negative or

\footnotetext{
${ }^{1}$ This rate represents the difference between the number of immigrants and emigrants of a country during a period of time (typically a year), divided per 1,000 inhabitants. A positive value indicates more people entering the country than leaving it, while a negative value means more people leaving than entering it.
} 
zero, which indicates an underlying strong emigration trend. In 2015, the total stock of Lebanese emigrants, stood at around 1.9 million out of total population of 4.5 million according to the United Nations with females constituting around 52\% of emigrants. Additional data from the same source shows that those aged between 20 and 64 years constitute the majority of emigrants. They accounted for $50.7 \%$ of emigrants in 2015, while those below aged 20 years constituted 46\% (United Nations, Department of Economic and Social Affairs, Population Division). These figures show that in Lebanon, youth emigration is an important phenomenon.

In this respect, examining factors affecting the decision of youth to emigrate calls for understanding the context that "pushes" young people to leave their country of origin (push factors) in addition to the context in the host country that creates better opportunities for the migrant youth (pull factors). Both push and pull factors can be classified into macroeconomic and microeconomic drivers. Push and pull factors are examined in studies on emigration (e.g. Jenkins, 1977; Akokpari, 2000; Hare, 1999). From a microeconomic or socio-economic perspective, push factors relate to the economic environment of the household in which youth live, while pull factors are intimately related to the macroeconomic ones in host countries since they define the expected living conditions of the emigrant. As a matter of fact, household characteristics represent a major economic factor that pushes young people to emigrate. Such factors include parents' income, the size of the household, geographic location, among others. Exploring these microeconomic factors is the main objective of this paper. This paper aims at understanding the role of socio-economic factors, which may affect the propensity to emigrate amongst the youth in Lebanon. Specifically, it focuses on the implications of youth, household, and regional characteristics using a probit model.

The remainder of the paper is organized as follows. In Section 2, we provide a historical background on emigration in Lebanon. In Section 3, an overview of the related literature on the determinants of migration is presented. In Section 4, we present the research methodology including the data, the variables of interest, and the estimation techniques. In Section 5, we present the empirical results. In Section 6, we discuss policy implications and concluding remarks. 


\section{Historical background}

Modern Lebanese emigration goes back to the $19^{\text {th }}$ century and has witnessed four migratory waves. During the 19th century, Lebanese mostly migrated to Latin America escaping internal and external conflicts and the dire conditions generated by economic crises in hope of seeking better living conditions and fortunes abroad. In contrast, today, highly skilled Lebanese choose to move to Arab Gulf countries such as Bahrain, Kuwait, Qatar, Saudi Arabia and United Arab Emirates (Migration Policy Center, 2013) in search of jobs and higher wages. As such, each wave have had different characteristics and patterns, yet, almost all waves had a predominantly youth component.

The first wave took place under the Ottoman Empire between 1880 and 1914, which was promoted by accommodating immigration policies in the Americas towards Christian subjects of the Ottoman Empire. Emigration began to increase during the 2nd half of the 19th century long before the creation of the state of Lebanon. 'Syrio-Lebanese' was the term used to describe the emigrants from Ottoman provinces of Greater Syria. During that period, it was estimated that around 100,000 'Syrio-Lebanese' left their home country. In the 1890s, Lebanese migration was not simply restricted to searching for a better life; young Lebanese migrated to avoid Ottoman military drafts as well. Others chose to migrate to emulate the success of their earlier brethren living abroad (Fersan, 2010). Proto-Lebanese migrants mainly left to Egypt and the United States; usually settling in New York, Philadelphia, and Chicago. Afterwards, the level of emigration from Mount Lebanon (mainly Christian) decreased. This drop, coupled with an increase in population growth engendered by a fast fall in the mortality rate, pushed inhabitants in Mount Lebanon to move to the provincial capital Beirut in search for better job prospects. As a result, the population in Beirut quadrupled between 1830 and 1850, and then it doubled again between 1865 and 1920. This led to a huge demographic imbalance and pushed less educated people to search for jobs outside what later became known as Greater Lebanon. ${ }^{2}$ Many researches emphasize that by 1914, at least a quarter of the Lebanese population were emigrants. This had an impact on economy and society. Specifically, it affected employment, wages, prices and productivity patterns (Owen, 1992).

\footnotetext{
${ }^{2}$ In 1920, Greater Lebanon (Le Grand Liban) was established as a national state under the French mandate (19181943).
} 
The second wave took place under the French Mandate and in the post-independence period (1918-1974). After the end of World War I, specifically between 1930 and 1940, the number of Lebanese emigrants decreased, due to migration quotas imposed by the United States in 1924. Moreover, Lebanon's economic stability under the French mandate (1918-1943) encouraged the Lebanese to stay in their home country (Owen, 1992). However, interestingly, the number of emigrant women increased substantially during this wave. The new destinations for Lebanese were Australia and West Africa (Fersan, 2010). After Lebanon's Independence in 1943, emigration continued to slow down but did not come to a halt. In the 1960s, emigration started to increase again after the Arab-Israeli war of 1967. This was engendered by the high unemployment rates and the increases in cost of living in Lebanon during that period. Additionally, there was a nascent high demand for skilled labor in Arab oil-producing countries resulting from the booming oil industry which culminated in the young Lebanese seeking employment in Saudi Arabia and Kuwait (Tabar, 2010).

The third wave took place during the Lebanese Civil War (1975-1990). Several factors such as political violence, forced displacement and the deterioration of economic conditions during the war pushed the young Lebanese to emigrate. The pace of emigration increased after the severe economic crisis that hit Lebanon in the mid-1980s that was accompanied by large scale currency devaluation and hyperinflation, in addition to a large increase in unemployment rate (Fersan, 2010). By the end of the war in 1990, and despite the return of some migrants either permanently or temporarily, it was clear that this war-induced emigration became more permanent.

The fourth and latest wave took place in the post-Civil War era (1990- Present). The 'Brain Drain' started to affect Lebanon during the 1990s where highly educated youth were driven to seek better employment opportunities and higher salaries abroad. During this wave, emigration increased as a result of poverty, corruption, political instability, housing crises, and the continuous rise of public debt (Fersan, 2010). ${ }^{3}$ In addition, continuous internal and external hostilities contributed to emigration during this period. The recent economic pressures and political instability that started in 2005 after the assassination of former prime minister Rafic Hariri, the summer 2006 Lebanon-Israel war, and the influx of Syrian refugees in the aftermath

\footnotetext{
${ }^{3}$ The latest figures show a persistent average poverty rate for Lebanon of 27\% (CAS and World Bank, 2015).
} 
of the Syrian crisis that started in 2011 are all important events that have constrained the growth potential and job creation prospects of the Lebanese economy. For example, in the aftermath of the Lebanon-Israel war in summer 2006, 53.4\% of those who emigrated did so in search of better job opportunities, $8.8 \%$ seeking advanced education, $25.4 \%$ due to family reasons while security and politics motivated $13.4 \%$ of them (Kasparian, 2010). This latest wave, which started in the 1990s, is the most youth orientated and mostly concerned with socio-economic problems. Interestingly, our data covers observations within this latest fourth wave of emigration.

\section{Macro and Micro Determinants of Migration}

In this section, we overview the main determinants of the decision of migrate. We first start by looking into macroeconomic factors, and then we focus on micro socio-economic determinants, which is the focus of this paper.

\subsection{Macroeconomic determinants}

Studies on macroeconomic determinants have focused on role of the aggregate economy (Akokpari, 2000), demographics (e.g. Hatton and Williamson, 2002; Mayda, 2010; Dreher et al., 2011), political stability (e.g. Hix and Noury, 2007; Dimant et al., 2013), and the environment (e.g. Beine and Parsons, 2015; Coniglio and Giovanni, 2015; Maurel and Tuccio, 2016). These factors reflect the economic environment of the country, which are reflected by indicators related to institutions, economic activity, political stability, and employment levels.

Currently, Lebanon is witnessing a number of problems ranging from large scale corruption in the government apparatus, slow economic growth, lack of job creation, poor public institutions, high levels of youth unemployment rate, to the Syrian crisis and its effects on the Lebanese

society. In fact, Lebanon ranks $123^{\text {rd }}$ on the corruption index out of 175 countries listed from the least to the most corrupt (Transparency International, 2015). These macroeconomic factors play a role in pushing the youth to emigrate. According to the World Bank (2012), the creating of jobs in the decade predating to the report was inadequate and informality has risen substantially. In the same report estimates show that in the following 10 years the Lebanese economy needs to create 5 times the amount of jobs currently created in order to absorb the new entrants into the labor market. The employment gap is estimated at 15,000 jobs yearly. Moreover, the report says that "Between 1997 and 2009, GDP grew at an average of 3.7 percent per year but employment 
expanded only by 1.1 percent. This indicates an employment-growth elasticity of only 0.2 , which is considerably lower than those observed in other countries in the region - South-Asia, Latin America, and Sub-Saharan Africa." (World Bank 2012, p. 14). In this respect, latest figures from the World Bank show that male and female youth unemployment rates in 2014 were $18.7 \%$ and 24.7\%, respectively (World Bank Development Indicators, 2015).

The World Bank (2012) considers youth unemployment an endemic problem in the Lebanese economy. It says "At one extreme are youth (age bracket 15-24) whose alarming unemployment rate -34 percent is explained by high entry rates. This high entry rate is, in part, a consequence of demographics; the growing working age population. The results suggest that youth entering the labor market are able to find jobs faster than other age groups, but the jobs they get, probably informal jobs or self-employment activities, are of short duration " (p. 17).

The causes of youth unemployment are multifaceted. These are inequalities in the educational system, low demand for skilled workers, and the high share of informal employment (Kawar and Tzannatos, 2012). Moreover, according to Kawar and Tzannatos (2012), there is a weak match between education and work which is an important determinant of youth employment and compensation. In general, only $40 \%$ of graduates work in jobs that match very well their qualifications while $20 \%$ work in occupations that do not match their educational fields. Moreover, the labor market is fluid as evidenced by the fact that currently the youth will have moved between ten and fourteen jobs by age 38. Moreover, the wage premium (as a measure of return to human capital) generated by education is low as the pay between educated and the noneducated is not very large.

In this respect, low wages in Lebanon also present a challenge to youth who face high costs of living. The cost of living reached extreme levels in the capital city Beirut after the civil war period. Beirut was ranked the $44^{\text {th }}$ most expensive major metropolitan area in the cost of living city ranking (Mercer, 2015). On the other hand, host countries provide elements that pull people to emigrate. Lebanese youth emigrate for better wage premiums with higher expected market return. These opportunities are found in the United States, Canada, Australia, European Union countries, and the Gulf countries. 


\subsection{Microeconomic (socio-economic) determinants}

Studies on microeconomic determinants of emigration have focused on the role of households and their perceptions about macroeconomic factors affecting their decisions to emigrate. To study the latter, empirical models based on household level surveys that control for household and youth characteristics are used. According to Rodriguez and Tiongson (2001), household characteristics play a decisive role in the decision to migrate. Such a decision has a number of implications on a household's allocation of resources and labor. This is to say that the decision to leave the country is not entirely related to youth characteristics where youth is targeting to maximize his/her own benefit, but also the decision is derived from the overall welfare level of the household (see Becker, 1981).

A survey of the microeconomic determinants of migration shows that gender, marital status, educational level, participation in the labor force, income level of the parents and youth, age, and household size are among the main indicators used in empirical studies. In one of the earliest studies, Gráda (1986), using a logit model to estimate the probability to migrate, finds that there is no difference between males and females in the decision to emigrate from Ireland, while the number of jobs held by the respondents is found to increase the likelihood to emigrate. Funkhouser (1992) finds that in Nicaragua emigration is increasing in household size, education, and age. In addition, emigrants are more likely to come from white-collar groups. Papapanagos and Sanfey (2001) use data from Albania to examine the determinants of the migration decision. Their results indicate that males and the educated are more likely to migrate, while age is found to have a negative effect. Moreover, their results show that income is not correlated with the decision to leave the country. Epstein and Gang (2006) examine the effects of household and friends' behavior on the decision to leave the country. Using data from Hungary, they find that male, younger, more educated individuals and those who live in urban areas are more likely to leave. However, they find that labor force participation did not affect the probability to migrate. In his paper, Hoti (2009) studies the determinants of emigration in Kosovo using a probit regression. He finds that younger people are more likely to emigrate, while marital status shows a mixed result between males and females. Household size is positively correlated with the decision to emigrate. Interestingly, the results show no significant difference between rural and urban areas and surprisingly, income is found to have no significant effect. In their seminal paper, Kennan and Walker (2011) develop a dynamic model of migration to explain the optimal 
sequences of the decision to migrate. Using US data from the National Longitudinal Survey of Youth, they conclude that the migration decision between states is substantially related to expected income. Gibson and McKenzie (2011) use a unique dataset on the best and brightest academic performers to examine the determinants of their migration from three pacific countries. The results reveal interesting findings. They indicate that the decision to move for this category of skilled people is highly correlated with their field of study in secondary schools. However, their decision is not correlated with income. In addition, gender is not found to be a significant variable.

More recently, Kahanec and Fabo (2013) use the Eurobarometer data to examine the determinants of the probability of youth to emigrate from one EU country to another. The findings show that married youth and males with children are more likely to migrate; however age is found to have a negative impact, while educational level is not an important driver for the decision to migrate inside the EU. Fetzer and Millan (2015) use data from Singapore and find that religion is not an important determinant for the decision to emigrate, while education is positively correlated with the decision, nonetheless age is found to be negatively correlated. The results also indicate that there is no difference between males and females' decisions. David and Jarreau (2016) examine the same research question using a probit regression with data from Egypt. They find that the wealthier is the household, the more likely is the individual to emigrate. Only secondary and tertiary education are found to be positively correlated with the emigration decision. They also find that being unemployed or underemployed are significant determinants. Bazillier and Boboc (2016) use a probit regression with data from the European Social Survey (2008) and find that gender and marital status are insignificant determinants of the emigration decision, while age has a negative impact. Their results also lend support to the Brain Drain hypothesis where skilled workers are more likely to emigrate than unskilled ones. Finally, being in an urban setting increases the propensity to emigrate.

Although, the above survey of the socio-economic literature on migration provides mixed evidence on the determinants of emigration, it allows us to identify to the most relevant factors behind the decision to emigrate, which guides our empirical examination in this paper. Indeed, this survey suggests that gender, age, employment status, educational level, and financial status of the youth are all important drivers of emigration. It also suggests that household and regional 
characteristics are all important drivers. This paper adds to the above mentioned strand of literature by providing new evidence from an AMC country, which is also a developing one.

\section{Methodology}

\subsection{Data}

In this paper, we use a unique and novel dataset from Lebanon. The data is retrieved from the SAHWA Youth Survey (2016), which is a nationally representative survey of 2,000 young respondents aged from 15 to 29 within private households.

The survey covers all six governorates of Lebanon. Each governorate is stratified into districts and then into villages and towns to ensure a proper representation in each geographic unit. The survey adopts a multi-stage probability sampling procedure to ensure a random, representative sample for identifying households and main respondents. The thematic axes around which the survey revolves are education, employment and social inclusion, political engagement, culture and values, international migration and mobility, gender.

\subsection{Variables and summary statistics}

The dependent variable under examination is defined as a binary variable taking the value one if the youth respondent indicated a willingness to emigrate or re-emigrate and takes the value of zero otherwise. Hence, our dependent variable signifies intentions to emigrate or to re-emigrate. The independent variables include youth, household, and regional characteristics. Specifically, we include the gender of the respondent defined as a binary variable that is equal to one if the respondent is male and zero otherwise. Unemployment status is captured by a binary variable that is equal to one if the respondent is unemployed and zero otherwise. The educational level of the respondent is also controlled for by a binary variable equal to one when the youth has university education and zero otherwise. ${ }^{4}$ A binary variable representing the financial support received from parents is also included, while another binary variable that captures explicit socio-

\footnotetext{
${ }^{4}$ By considering a binary variable for unemployment and university education, we aim to identify the pure effect of labor force participation and the pure effect of the highest level of education. It is important to mention that having a university degree is considered a key asset for youth in Lebanon since it allows him or her to be a potential worker in the host country, while having lower education such a secondary education is not considered as a good fit for a white-collar emigrant profile.
} 
economic concerns of the respondent is included. Household characteristics are captured by two independent variables. First, we create a dummy variable indicating whether or not the respondent has a capitalist parent ${ }^{5}$ This variable captures the occupation of the parents where the most financially capable occupation is the one where the parent(s) own their own businesses, which employ other workers. Second, we create a variable related to the roominess of the dwelling, which considers the ratio of the number of rooms in the household to its size in terms of inhabitants. This variable captures the assets of the household where the youth reside. Although both the capitalist and the roominess variables capture the wealth effect, they nevertheless do so it different ways since the capitalist variable reflects the occupation of the parents, while roominess captures their tangible assets.

Independent variables also include regional variables capturing the geographic distribution of the respondents. They include six regional dummies capturing all the Lebanese governorates. The residence area of the respondent is an additional variable that is captured by a binary variable that is equal to one when the residence is located in an urban setting and zero when it is in a rural one. Finally, we include a macroeconomic variable to control for regional differences in individual incomes across the six Lebanese governorates, which is captured by average regional individual expenditure. This latter variable is retrieved from the National Household Budget Survey (2012) of the Central Administration of Statistics (CAS). ${ }^{6}$

Table 1 shows the percentage of Lebanese youth expressing their willingness to emigrate in 2016 by characteristic. We observe that those among the youth, who have a capitalist parent and willing to emigrate, represent around $6 \%$ of the total sample. We also observe that $67 \%$ of those pro-emigration respondents are male, while $11 \%$ are unemployed and $41 \%$ of them have a university level of education. The data shows that around $38 \%$ of pro-emigration Lebanese youth have received financial support from their parents, while around $88 \%$ of them have explicitly voiced some socio-economic concerns. We notice only around 7\% of the Lebanese youth who are willing to emigrate are from the capital city Beirut, while Mount Lebanon governorate represents the highest share of around $24 \%$. The poorest governorate, North, also shows a high

\footnotetext{
${ }^{5}$ We definite a capitalist parent as a father who is both self-employed and an employer of others.

${ }^{6}$ It should be mentioned that National Household Budget Survey (2012) is the latest available national survey covering Lebanese households.
} 
figure of around $22 \%$. Finally, the data indicates that around $72 \%$ of those willing to emigrate live in urban areas.

Table 2 presents the descriptive statistics of the variables in 2016 that are used in our empirical analysis. The dependent variable shows that $16.5 \%$ of the respondents are willing to emigrate. Household characteristics show that $8.6 \%$ of youth have a capitalist parent. The average number of rooms per household inhabitant is equivalent to 1.3 rooms. This may suggest that the typical Lebanese household is not overcrowded. Moving to youth characteristics, we find that $50.3 \%$ of the youth respondents are male, $6.5 \%$ of them are employed, $38.1 \%$ have a university level education, 50\% have received financial support from parents, and 80\% voice explicit socioeconomic concerns. We find that $9.6 \%$ of the surveyed youth live in Beirut, $46.4 \%$ live in Mount Lebanon governorate, and $11.2 \%$ live in the poorest region, which is the North governorate. In addition, we observe that $77.2 \%$ of youth live in urban areas. Finally, the average regional individual expenditure is equal to 7.8 million Lebanese Pounds (US \$5,175) in the year 2012.

Table 3 represents the correlation matrix between some variables of interest. Although, simple correlations do not point to any form of causality, they nonetheless provide a preliminary indication about the sign of the relationship between the variables when the correlations are statistically significant. We find that being male and having socio-economic concerns are positively correlated with the willingness to emigrate. However, financial support received from

parents is negatively correlated with that willingness. It is interesting to note that having a capitalist parent and receiving financial support from parents are positively correlated. Finally, being unemployed is positively correlated with receiving financial support from parents.

\subsection{Empirical model}

The empirical investigation aims at identifying factors affecting the propensity of youth to emigrate. Let $E_{i}^{*}$ denote the prospective utility from emigrating accruing to the youth $i$ ( $i=$ $1, \ldots, I)$ who resides in governorate $g(g=1, \ldots, G)$. However, the variable $E_{i}^{*}$ is a latent variable and not observed in the data. Instead, what is observed is the decision to emigrate in a future stage. Therefore, we use a probit specification to model the propensity to emigrate. The probit model can be presented as:

$$
E_{i}^{*}=H_{i} \beta+Y_{i} \alpha+Z_{g}+u_{i}
$$


With the following probit rule:

$$
E_{i}=\left\{\begin{array}{ll}
1 & \text { if } \quad E_{i}^{*} \geq 0 \\
0 & \text { if } \quad E_{i}^{*}<0
\end{array},\right.
$$

where $E_{i}$ is a binary variable that equals one if the youth respondent indicated a willingness to emigrate and zero otherwise, $H_{i}$ is the vector of variables representing household characteristics where the youth resides, $Y_{i}$ is a vector of variables representing youth characteristics, $Z_{g}$ is the national indicator of governorate $g$, and $u_{i}$ is the error term.

The above probit model is estimated using the cumulative standard normal distribution function represented as follows:

$$
E\left(E_{i} \mid H_{i}, Y_{i}, Z_{g}\right)=\Phi\left(H_{i} \beta+Y_{i} \alpha+Z_{g}\right)
$$

\section{Empirical results}

The estimation results of the probit model are presented in Table 4. Column (1) controls for household characteristics, while column (2) controls for regional effects only. In columns (2) and (3) we combine both household and regional characteristics. However, in column (4) we control for youth characteristics only, while column (5) combines household and youth characteristics and column (6) shows the results of both youth and regional characteristics. Finally, column (7) presents the full model that includes youth, household, and regional characteristics. The last column, i.e. column (8), controls for a relevant macroeconomic indicator, which is the average regional individual expenditure, while keeping both youth and household characteristics.

The design of our dataset allows us to control for two interesting variables, which are: capitalist parent and roominess of the dwelling. These variables are specifically relevant for developing countries that are usually characterized by with the existence of what we can call two parallel economic systems where youth from poor and marginalized backgrounds are excluded from economic opportunities. The results of the household characteristics show that having a capitalist parent decreases significantly the propensity of youth to emigrate across all eight specifications. The marginal effect ranges from 0.034 in column (8) to 0.059 in column (1) indicating that having a capitalist parent decreases the propensity of youth to emigrate. The range of decrease is 
between 3.4 and 5.9 percentage points. Moving to roominess, the results also reveal negative and significant results in all specifications. In the full models (7) and (8), we find that a one hundred percentage point increase in roominess decreases the propensity to emigrate by around five percentage points. Thus, less crowded households will make the youth less likely to seek to emigrate.

Turning to youth characteristics, we find that being male increases the propensity of youth to emigrate by an average of 10 percentage points. This result is significant across all specifications in columns (4) to (8) in line with the findings of Papapanagos and Sanfey (2001) from Albania, Epstein and Gang (2006) from Hungary, and Kahanec and Fabo (2013) from the EU but contradicts those of Gráda (1986) from Ireland and Hoti (2009) from Kosovo. Being unemployed is also positively correlated with the willingness to emigrate in line with recent evidence from other Arab Mediterranean countries such as Egypt (David and Jarreau, 2016). Unemployment increases the propensity to emigrate by around 14 percentage points in the full model presented in columns (7) and (8). Having a university education level increases the propensity to emigrate by around 4.4 percentage points in line with the findings of Funkhouser (1992) from Nicaragua, Papapanagos and Sanfey (2001), Epstein and Gang (2006), and Fetzer and Millan (2015) from Singapore. However, the result on education is not in line with evidence reported by Kahanec and Fabo (2013) from EU, since in their case, would be emigrants are moving inside the same economic region, which is the EU. Yet, in Lebanon, higher education is seen as a mean to increase the chances of winning what we can call the 'emigration lottery' and realizing the wage premiums that education potentially entitles them to. Indeed, according to the results from the SAHWA ethnographic study in Lebanon (National Case Study, 2016) a number of interviewed youth, who have university level education, expressed serious concerns about their ability to find jobs that match their education profile in Lebanon. Stylized facts reported by Kawar and Tzannatos (2012) support this idea where Lebanon ranks first in Middle East countries in terms of high skilled emigration rate to Organization of Economic Cooperation and Development (OECD) and Gulf Cooperation Council (GCC) countries.

Interestingly, the results indicate that youth receiving financial support from parents are less likely to emigrate. The corresponding marginal effect implies a decrease by 7.7 percentage points in the full model that is reported in column (7) and 7.9 percentage points in column (8). 
This result seems to suggest that the wealth level of the household is taken into consideration by youth when he or she decides to emigrate (David and Jarreau, 2016). This effect reinforces the negative effect of having a capitalist parent has on the willingness to emigrate. Finally, the socioeconomic concerns of youth indicate a positive marginal effect. Specifically, the results reveal that having explicit socio-economic concerns increases the propensity to emigrate by 4.5 and 4.2 percentage points in columns (7) and (8), respectively.

The estimation of the effects of the regional distribution across governorates shows interesting results. Compared to the capital city Beirut, which is taken as the reference group, we find that the poorest governorates i.e. North and Beqaa have the highest propensity to migrate. However, youth living in Mount Lebanon governorate, which is considered a relatively rich region compared to other regions, are less inclined to emigrate. Finally, living in the South governorate leads to a positive but small effect on the willingness to emigrate. Moreover, urbanism seems not be a relevant determinant in the decision to emigrate. The corresponding marginal effect shows a negative implication on the decision to emigrate, however, this effect is only significant at the $10 \%$ level of significance in columns (2) and (3). This result becomes insignificant when running the full model in column (7) suggesting that there is no difference between youth living in rural or urban areas with regards to their decision to emigrate. This latter result is not in line with the findings on Hungary by Epstein and Gang (2006) and on Egypt by David and Jarreau (2016), which have a much larger rural population than Lebanon.

Finally, the effect of the macroeconomic indicator that measures the average regional expenditure is negative and significant as shown in column (8). Specifically, we find that increasing the regional individual expenditure by 10 percentage points reduces the propensity to emigrate by 0.81 percentage points. This result reinforces the results stemming from the examination of the regional distribution of youth, which indicates that poorer areas are more likely to host young persons with a stronger desire to emigrate.

\section{Conclusions}

This paper identifies a number of labor market and socio-economic constraints, which negatively impact youth employability, pushing young Lebanese to increase their willingness to emigrate. This type of migration has drawn considerable attention among academics and policymakers 
(Docquier et al., 2007). Using a unique dataset on youth, we establish a socio-economic profile for a typical young Lebanese who demonstrates a willingness to emigrate. The empirical results reveal that youth from non-wealthy backgrounds living in smaller dwellings have a higher propensity to emigrate. This result points to the fact that ownership of capital increases the parents' ability to provide their dependents with enhanced economic conditions and acts as a deterrent to emigration of youth living in well-off households. It is also found that being male and unemployed has a positive incidence on migration. Moreover, university education promotes the willingness to emigrate; while residents of poor regions are more likely to express such willingness. Overall, the willingness to emigrate can be seen as a proxy for severe constraints limiting the economic opportunities of youth. The large heterogeneity in employment conditions between Lebanon and host countries acts hence as gradient driving migration flows as it solves the national problem of labor market mismatch and the poor working conditions of the home country as advanced by Bazillier and Boboc (2016).

The quantitative results from our paper are in line with the qualitative results from the ethnographic fieldwork on Lebanese youth (National Case Study for Lebanon, SAHWA Project, 2016). As we found in this paper, the poorest regions showed the highest propensity to migrate, while those youth with explicit socio-economic concerns did the same. Indeed, the majority of participants in the focus group meetings have reported that the current educational system, nepotism and favoritism, as well as the available jobs constitute the major problems facing youth in Lebanon. In other words, there is a similarity between macroeconomic concerns expressed in the ethnographic study and the quantitative results that emerged from the socio-economic analysis in our paper. This suggests that socio-economic concerns such as aversion to corruption and weak political representation and lack of opportunities in poor areas including unemployment are in line with macroeconomic problems that shape the life of youth in Lebanon. These observations also coincide with the observations made on the role that connections within the Lebanese political system has on economic outcomes (Stel and Naudé, 2016). These problems, among others discussed earlier, constitute the major constraints pushing Lebanese youth to voice their willingness to migrate which in the end aims at enhancing their ability to have better job and life prospects. 
From a macroeconomic perspective it is known that youth emigration, despite having a positive effect on financial flows into the country in form of immigrant remittances, constitutes a brain drain that affects negatively economic growth and human capital accumulation. Therefore, policy interventions are needed to abate the propensity to migrate to order to avoid these negative macroeconomic implications. Yet, policy interventions to be effective need to be tailored at the socio-economic level. Hence, our paper, which clarifies the determinants of youth emigration in Lebanon, helps policy makers identify various points of policy interventions to deal with the problem of emigration. The interventions are mainly to be implemented in the areas of education and the labor market. Such policies are first, improving the education-to-work transitions for young people; second, solving the skill mismatch problem in the labor market by devising policies that encourage job creation in productive sectors that create demand for skilled workers; third, reducing regional disparities in income and wealth; and finally, institute a wageled growth regime (Lavoie and Stockhammer, 2012) that would improve wages that would solve both the education premium problem in Lebanon in addition to creating a dynamic economy with good job creation prospects. Finally, these policy implications re-inforce those discussed recently by Dibeh et al. (2016) who conclude that there are three severe employment constraints that affect youth employability in Lebanon, which are the rigidity of labor regulations in addition to the skill mismatch problem and poor governance in public institutions. 


\section{References}

Akokpari, John K. "Globalisation and migration in Africa". African Sociological Review/Revue Africaine de Sociologie, vol. 4 (2000), P.72-92.

Bazillier, Rémi, and Cristina Boboc. "Labour migration as a way to escape from employment vulnerability? Evidence from the European Union". Applied Economics Letters, (2016), forthcoming.

Becker, Gary (eds.). A Treatise on the Family, Harvard: University Press, 2009.

Beine, Michel, and Christopher Parsons. "Climatic factors as determinants of international migration”. Scandinavian Journal of Economics, vol. 117 (2015), P.723-767.

Borjas, George. "Economic theory and international migration”. International Migration Review, vol. 23 (1989), P.457-485.

Borjas, George J., and Bratsberg, Bernt. "Who Leaves? The Outmigration of the Foreign-Born". Review of Economics and Statistics, vol. 78 (1996), P.165-176.

CAS and World Bank Snapshot of Poverty and Labor Outcomes in Lebanon. Beirut, Lebanon (2015).

Coniglio, Nicola D., and Giovanni Pesce. "Climate variability and international migration: an empirical analysis". Environment and Development Economics, vol. 20 (2015), P.434-468.

David, Anda, and Joachim Jarreau. "Determinants of Emigration: Evidence From Egypt". Economic research forum (ERF) - Egypt (2016), (on-line) [Date accessed 8.10.2016] erf.org.eg/wp-content/uploads/2016/04/987.pdf

Dibeh, Ghassan, Fakih, Ali, and Marrouch, Walid. "The Poor and Marginalized in Lebanon: Labor Market Challenges and Policy Implications". Sahwa Policy Paper, 01, CIDOB Barcelona (2016) (on-line) [Date accessed 9.9.2016] http://www.sahwa.eu/NEWS/SAHWA-sPolicy-Paper-on-labour-market-in-Lebanon-now-online

Dimant, Eugen, Tim Krieger, and Daniel Meierrieks. "The effect of corruption on migration, 1985-2000”. Applied Economics Letters, vol. 20 (2013), P.1270-1274.

Docquier, F., Lohest, O. and Marfouk, A. "Brain drain in developing countries". World Bank Economic Review, vol. 21 (2007), P.193-218.

Dreher, Axel, Tim Krieger, and Daniel Meierrieks. "Hit and (they will) run: The impact of terrorism on migration”. Economics Letters, vol. 113 (2011). P.42-46.

Epstein, Gil S., and Ira N. Gang. "The influence of others on migration plans". Review of Development Economics, vol. 10 (2006), P.652-665.

Fersan, Eliane. "Syro-Lebanese Migration (1880-Present): "Push" and "Pull" Factors". Migration in the Mashreq, Viewpoints, Middle East Institute, Washington, D.C., (2010), P.1317. 
Fetzer, Joel S., and Brandon Alexander Millan. "The Causes of Emigration from Singapore: How Much Is Still Political?” Critical Asian Studies, vol. 47 (2015), P.462-476.

Funkhouser, Edward. "Migration from Nicaragua: some recent evidence". World Development, vol. 20 (1992), P.1209-1218.

Gibson, John, and David McKenzie. "The microeconomic determinants of emigration and return migration of the best and brightest: Evidence from the Pacific". Journal of Development Economics, vol. 95 (2011), P.18-29.

Hare, Denise. "Push versus pull factors in migration outflows and returns: Determinants of migration status and spell duration among China's rural population". The Journal of Development Studies, vol. 35 (1999), P.45-72.

Hatton, Timothy J., and Jeffrey G. Williamson. "Out of Africa? Using the past to project African emigration pressure in the future". Review of International Economics, vol. 10 (2002), P.556573.

Hix, Simon, and Abdul Noury. "Politics, Not Economic Interests: Determinants of Migration Policies in the European Union”. International Migration Review, vol. 41 (2007), P.182-205.

Hoti, Avdullah. "Determinants of emigration and its economic consequences: evidence from Kosova”. Southeast European and Black Sea Studies, vol. 9 (2009), P.435-458.

Jenkins, J. Craig. "Push/pull in recent Mexican migration to the US". International Migration Review, vol. 11 (1977), P.178-189.

Kahanec, Martin, and Brian Fabo. "Migration strategies of crisis-stricken youth in an enlarged European Union". Transfer: European Review of Labour and Research, vol. 19 (2013), P.365380.

Kasparian, Choghig. “L’émigration des jeunes Libanais hautement qualifiés”. (2010).

Kawar, M. and Z. Tzannatos. "Youth Employment in Lebanon: Skilled and Jobless". LCPS Policy Paper, (2012). Beirut, Lebanon.

Kennan, John, and James R. Walker. "The effect of expected income on individual migration decisions". Econometrica, vol. 79 (2011), P.211-251.

Lavoie, M. and E. Stockhammer (2012) "Wage-led growth: Concept, theories and policies," ILO Conditions of Work and employment Series No. 41

Maurel, Mathilde, and Michele Tuccio. "Climate Instability, Urbanisation and International Migration”. Journal of Development Studies, vol. 52 (2016), P.735-752.

Mayda, Anna Maria. "International migration: A panel data analysis of the determinants of bilateral flows". Journal of Population Economics, vol. 23 (2010), P.1249-1274.

MERCER. "Cost of Living City Ranking". (2015), (on-line) [Date accessed 4.8.2016] Retrieved from https://www.imercer.com/uploads/GM/col2015/f123654/index.html 
MPC Team Migration Policy Center, Lebanon. (2013), P. 1-2.

NCS, National Case Study for Lebanon. SAHWA Project, (2016) (NCS-LB-1)

Gráda, Cormac, Ó. "Determinants of Irish emigration: a note". International Migration Review, vol. 20 (1986), P.650-656.

Owen, Rogers. "Lebanese migration in the context of world population movements", in Albert Hourani and Nabil Shehadi (eds). Lebanese Migration in the World: A Century of Emigration, (1992), P.605-626. London: Centre for Lebanese Studies.

Papapanagos, Harry, and Peter Sanfey. "Intention to emigrate in transition countries: the case of Albania". Journal of Population Economics, vol. 14 (2001), P.491-504.

Rodriguez, Edgard and Erwin Tiongson. "Temporary migration overseas and household labor supply: evidence from urban Philippines". International Migration Review, vol. 35 (2001), P.709-725.

SAHWA Youth Survey, Barcelona Centre for International Studies (CIDOB), Barcelona, Spain, (2016).

Stel, Nora, and Wim Naudé. "Public-Private Entanglement: Entrepreneurship in Lebanon's Hybrid Political Order". Journal of Development Studies 52, (2016), P.254-268.

Tabar, Paul. "Lebanon: A country of Emigration and Immigration". Institute for Migration Studies (2010).

Transparency International. "Corruption Perceptions Index". (2015), (on-line) [Date accessed 4.8.2016] https://www.transparency.org/

United Nations. "Department of Economic and Social Affairs, Population Division". (2015), (online) [Date accessed 4.8.2016] https://esa.un.org/unmigration/

World Bank (2012) Lebanon: Good Jobs Needed: MILES Report. World Bank Publications.

World Bank. "World Development Indicators (WDI) Database". World Bank - Washington DC (2015), (on-line) [Date accessed 4.8.2016] http://data.worldbank.org/indicator/SM.POP.NETM 
Table 1: Percentage of youth expressing their willingness to emigrate by characteristic

\begin{tabular}{ll}
\hline Variable & Percentage \\
\hline Youth willing to emigrate: & \\
With a capitalist parent & 5.94 \\
Is male & 66.56 \\
Is unemployed & 10.63 \\
Has a university education & 41.25 \\
Has financial support from parents & 38.44 \\
Has socio-economic concerns & 88.44 \\
& \\
Youth willing to emigrate are from: & \\
Beirut & 6.88 \\
Mount Lebanon & 24.38 \\
North & 22.19 \\
Akkar & 6.25 \\
South & 12.81 \\
Nabatieh & 7.50 \\
Baalbek & 7.81 \\
Beqaa & 12.19 \\
& \\
Youth willing to emigrate are from: & \\
Urban areas & 71.56 \\
\hline Number of observations & 2,000 \\
\hline
\end{tabular}


Table 2: Descriptive statistics of variables used in the analysis

\begin{tabular}{lll}
\hline Variable & Mean & Standard Deviation \\
\hline Dependent variable & & \\
Youth willing to emigrate & 0.165 & 0.371 \\
& & \\
Household characteristics & & \\
With a capitalist parent & 0.086 & 0.281 \\
Roominess: ratio of number of rooms to household size & 1.295 & 0.653 \\
Youth characteristics & & \\
Male & 0.503 & 0.500 \\
Unemployed & 0.065 & 0.247 \\
University education & 0.381 & 0.486 \\
Financial support from parents & 0.500 & 0.500 \\
Socio-economic concerns & 0.798 & 0.401 \\
Regional dummies & & \\
Capital city & & \\
Beirut & 0.096 & 0.294 \\
Governorates & & \\
Mount Lebanon & 0.464 & 0.499 \\
North & 0.112 & 0.316 \\
Akkar & 0.047 & 0.212 \\
South & 0.099 & 0.299 \\
Nabatieh & 0.068 & 0.252 \\
Baalbek & 0.054 & 0.227 \\
Beqaa & 0.055 & 0.229 \\
Residence area & & \\
Urban & 0.772 & 0.420 \\
Average regional individual expenditures (Millions LBP) & 7796.362 & 1008.862 \\
\hline Number of observations & 2,000 & \\
\hline & & \\
\hline
\end{tabular}


Table 3: Correlation matrix

\begin{tabular}{|c|c|c|c|c|c|c|c|c|}
\hline & $\begin{array}{l}\text { Youth } \\
\text { willing to } \\
\text { emigrate }\end{array}$ & $\begin{array}{l}\text { With a } \\
\text { capitalist } \\
\text { parent }\end{array}$ & $\begin{array}{l}\text { Number of } \\
\text { rooms/Household } \\
\text { size ratio } \\
\end{array}$ & Male & Unemployed & $\begin{array}{l}\text { University } \\
\text { education }\end{array}$ & $\begin{array}{l}\text { Financial } \\
\text { support from } \\
\text { parents }\end{array}$ & $\begin{array}{l}\text { Socio- } \\
\text { economic } \\
\text { concerns }\end{array}$ \\
\hline Youth willing to emigrate & 1.000 & & & & & & & \\
\hline With a capitalist parent & -0.045 & 1.000 & & & & & & \\
\hline $\begin{array}{l}\text { Roominess: ratio of } \\
\text { number of rooms to } \\
\text { household size }\end{array}$ & -0.053 & -0.002 & 1.000 & & & & & \\
\hline Male & $0.146^{*}$ & 0.000 & -0.007 & 1.000 & & & & \\
\hline Unemployed & 0.075 & -0.038 & -0.035 & -0.054 & 1.000 & & & \\
\hline University education & 0.032 & 0.052 & $0.136^{*}$ & -0.015 & -0.049 & 1.000 & & \\
\hline $\begin{array}{l}\text { Financial support from } \\
\text { parents }\end{array}$ & $-0.102 *$ & $0.137 *$ & $-0.194 *$ & -0.013 & $0.183^{*}$ & -0.028 & 1.000 & \\
\hline Socio-economic concerns & $0.094 *$ & 0.066 & -0.075 & 0.059 & 0.030 & 0.062 & 0.079 & 1.000 \\
\hline
\end{tabular}

Notes: Correlation coefficients with Bonferroni-adjusted significance levels. $*=10 \% ; * *=5 \%$; $* *=1 \%$. 
Table 4: The determinants of the youth emigration decision (probit model, marginal effects)

$\begin{array}{lllllll}(1) & (2) & (3) & \text { (4) } & \text { (5) } & \text { (6) }\end{array}$

\section{Household characteristics}

With a capitalist parent

$-0.059$

$(0.024)^{* *}$

Roominess: ratio of number

of rooms to household size

$-0.033$

$(0.016)^{* *}$

\section{Youth characteristics}

Male

Unemployed

University education

Financial support from parents

Socio-economic concerns

\section{Regional dummies}

Akkar

Baalbek

North

South

Mount Lebanon

Nabatieh

$$
\begin{array}{ll}
0.104 & 0.110 \\
(0.003)^{* * *} & (0.007)^{* * *}
\end{array}
$$$$
0.123 \quad 0.130
$$$$
(0.046)^{* * *} \quad(0.046)^{* * *}
$$$$
0.258 \quad 0.279
$$$$
(0.044)^{* * *} \quad(0.026)^{* * *}
$$$$
0.209 \quad 0.195
$$$$
(0.043)^{* * *} \quad(0.043)^{* * * *}
$$$$
0.106 \quad 0.088
$$$$
(0.014)^{* * *} \quad(0.004)^{* * *}
$$$$
-0.046 \quad-0.051
$$$$
(0.015)^{* * *} \quad(0.012)^{* * *}
$$$$
0.079 \quad 0.060
$$$$
(0.020)^{* * *} \quad(0.011)^{* * *}
$$

\section{Residence area}

Urban

$$
\begin{array}{ll}
-0.011 & -0.012 \\
(0.006)^{*} & (0.006)^{*}
\end{array}
$$

$\begin{array}{lllll}0.105 & 0.104 & 0.105 & 0.105 & 0.103 \\ (0.008) * * * & (0.005)^{* * *} & (0.002) * * * & (0.002) * * * & (0.001) * * * \\ 0.178 & 0.174 & 0.142 & 0.137 & 0.140 \\ (0.014) * * * & (0.021)^{* * *} & (0.003) * * * & (0.005)^{* * *} & (0.008) * * * \\ 0.027 & 0.037 & 0.032 & 0.043 & 0.044 \\ (0.014)^{*} & (0.016)^{* *} & (0.001)^{* * *} & (0.002)^{* * *} & (0.003) * * * \\ -0.095 & -0.100 & -0.070 & -0.077 & -0.079 \\ (0.020) * * * & (0.021)^{* * *} & (0.020) * * * & (0.022)^{* * *} & (0.021)^{* * *} \\ 0.083 & 0.080 & 0.057 & 0.054 & 0.052 \\ (0.018) * * * & (0.016)^{* * *} & (0.029) * & (0.028)^{* *} & (0.021)^{* *}\end{array}$

$\begin{array}{ll}0.074 & 0.082\end{array}$

$(0.009)^{* * *} \quad(0.024)^{* * * *}$

$0.102 \quad 0.112$

$(0.046)^{* *} \quad(0.047)^{* *}$

$0.245 \quad 0.270$

$(0.033)^{* * *} \quad(0.017)^{* * *}$

$0.186 \quad 0.171$

$(0.039)^{* * *} \quad(0.035)^{* * *}$

$0.074 \quad 0.057$

$(0.013)^{* * *} \quad(0.005)^{* * *}$

$-0.041 \quad-0.046$

$(0.018)^{* *} \quad(0.016)^{* * * *}$

$0.069 \quad 0.048$

$(0.008)^{* * *} \quad(0.003)^{* * *}$

$\begin{array}{ll}-0.003 & -0.003\end{array}$

(0.003) (0.003)

\section{Macro variable}

Average regional individual expenditures

\begin{tabular}{lllllllll}
\hline Ln-Likelihood (pseudo) & -864.015 & -808.515 & -801.963 & -817.766 & -811.306 & -769.161 & -760.715 & -768.975 \\
Number of observations & 2,000 & 2,000 & 2,000 & 2,000 & 2,000 & 2,000 & 2,000 & 2,000 \\
\hline
\end{tabular}

Notes: Statistical significance: $*=10 \% ; * *=5 \% ; * * *=1 \%$. Robust and residence area clustered standard errors are in parentheses. 